\title{
Lucia Ceci
}

The Vatican and Mussolini's Italy. Trans. Peter Spring. Leiden: Brill, 2017. Pp. vi + 343. $\mathrm{Hb}, \$ 151$.

Lucia Ceci is an accomplished historian of modern history, and the translation of her recent book, The Vatican and Mussolini's Italy, will be of great interest to a range of English-language readers. The book traces what Ceci calls the "dynamics of rivalry, defense and mutual influence" that characterized relations between the Holy See and the fascist regime in Italy from 1922 until World War II (6). The book also investigates the crucial role played by leading members of the Society of Jesus, such as Father Pietro Tacchi Venturi, in establishing dialogue between the Vatican and fascist officials. Ceci, who teaches history at the Università Roma II, has expertise in the history of liberation theology and in the Catholic Church's attitudes during the fascist war in Ethiopia. Her latest book provides a broader sweep than her previous publications. Through its comprehensive analysis of church-state relations during the fascist years, Ceci's book is on par with works by the likes of John Pollard, who through his The Vatican and Italian Fascism (Cambridge: Cambridge University Press, 1985), or, more recently The Papacy in the Age of Totalitarianism (Oxford: Oxford University Press, 2014), helped establish the gold standard in the field. The Italian-language version of Ceci's book, entitled, L'interesse superiore. Il Vaticano e l'Italia di Mussolini (Rome-Bari: Laterza, 2010), achieved a good amount of attention in Italy, and won the "Friuli Storia" prize in 2014.

Based on an impressive review of secondary literature and on some original archival research as well, The Vatican and Mussolini's Italy argues that the church and Italian state had a close working relationship throughout the twenty years of fascist rule. This relationship, Ceci notes, was consolidated by a shared perception with common enemies, including Protestants, liberals, and communists. She looks in particular at how this relationship was mediated by figures such as the Jesuit Pietro Tacchi Venturi, who served as a go-between for the Vatican and the fascist regime both in the years of Pius XI and of Pius XII. Provocatively, in keeping with the scholarship of David Kertzer and other historians, Ceci suggests that fascist antisemitism cannot be understood outside of a much longer history of Christian antisemitism. As the book shows, Christian antisemitism and anti-Jewish prejudice had a long history in Italy and Europe, and rather than being challenged or silenced in 1937-38 (as Mussolini issued Italy's race laws), upper clergy revived these prejudices, as did fascists themselves. As Ceci argues, most Catholics responded with complicity to the fascist antisemitic laws and practices of the late 1930s. When Pope Pius 
XI belatedly decided to take a stand against antisemitism in 1938-39, he found himself isolated, and the Roman Curia quickly silenced his efforts. Ceci does not, however, address the thorny question of how far Pius XI's condemnation of racism went or did not go-a question tackled head-on more recently by scholars like John Connelly.

Ceci's book charts a longer history than one might initially assume. Rather than beginning in 1922, the book starts with Benito Mussolini's childhood in the late nineteenth century. Though Mussolini's upbringing and his early influences are beautifully and accurately narrated, one wonders why Ceci chose to begin her book in this way. After all, the fascist regime was larger than one man, and church-state relations during the 1920s and 1930s were dictated by much more than Mussolini's personal feelings about Catholicism and the church. More relevant is the issue of how Catholics in Italy positioned themselves during World War I-a topic the book gets to halfway through the first chapter. Here, we begin to understand the nationalization of Italian Catholicism, and the decision of the church to prove its patriotic spirit by attempting to make peace with the Italian state. Suddenly, the "exception" of the Lateran Agreements appears more like the norm of the 1920 s church.

The remainder of the book proceeds by reinforcing chronologies familiar to scholars in the field: Ceci concurs that the early fascist years were marked by Mussolini's attempt to court the church and the church's interest in forging a partnership with the regime; she reinforces 1931 as a year of crisis in churchstate relations, largely because of a conflict over the Catholic civil society organization, Catholic Action; she addresses the puzzle faced by Pius XI when it came to taking a position on the Ethiopian war of 1935; she discusses the 1938 church-state clash; and so forth. Following scholars like Emma Fattorini, Ceci paints a picture of Pius XI as a pope who was increasingly coming unglued from both his flock and the upper clergy. This disconnect increased in 1935 with the Ethiopian war, as bishops and Catholic civil society members rushed to celebrate the conflict, even as Pius XI hung back and expressed his concerns and criticisms in private. The gap widened with the Italian race laws, which Pius XI protested, but which Italian Catholics and the upper clergy accepted or even celebrated.

Grounded in a deep reading of the secondary sources and a judicious assessment of archival material, Ceci's account is a scholarly synthesis of the first order. Following historians like Giovanni Miccoli, Ceci suggests that the relationship between church and state was characterized by a constant tug of war. This was dictated by the fact that both church and state were, in an important sense, "totalitarian" in their ambitions, in that they hoped to exercise total power over individuals. In this sense, both were profoundly undemocratic and 
unwilling to accept a modern and pluralist social ordering. At the same time, the interpretation of the church as "totalitarian" does not sit that comfortably with Ceci's parallel thesis, namely that of a brave and lonely Pius XI, who sought to fight fascism almost single-handedly.

The Vatican and Mussolini's Italy, much as it will please the non-specialist and offer a useful and readable overview of a fractious period in church history, does not push the envelope when it comes to the scholarly understanding of this historical period. Rather than challenging existing historiographical interpretations, Ceci tends to reaffirm them. And though the book is richly documented and quite balanced in its assessments, one wishes that Ceci had gone beyond the available interpretative frameworks, to offer a richer analysis on any of a series of questions she raises only in passing, including why liberalism and communism so terrified the church, how transnational European affairs factored into the Vatican's relations with Italy, and how, precisely, Catholic anti-Judaism inflected fascist antisemitism. Nonetheless, despite these minor misgivings, the book certainly deserves a spot on the shelf of any scholar and general reader interested in church-state relations in the tumultuous years between World War I and World War II.

\section{Giuliana Chamedes}

University of Wisconsin at Madison

chamedes@wisc.edu

DOI:10.1163/22141332-00503007-14 